\title{
The nature of the crust under Cayman Trough from gravity
}

\author{
Uri S. ten Brink ${ }^{\mathrm{a}, *}$, Dwight F. Coleman ${ }^{\mathrm{b}, \mathrm{c}}$, William P. Dillon ${ }^{\mathrm{a}}$ \\ ${ }^{\mathrm{a}}$ United States Geological Survey, Woods Hole Field Center, 384 Woods Hole Road, Woods Hole, MA 02543, USA \\ ${ }^{\mathrm{b}}$ Institute for Exploration, Mystic, CT, USA \\ ${ }^{\mathrm{c}}$ Graduate School of Oceanography, University of Rhode Island, Narragansett, RI, USA
}

Received 31 May 2002; received in revised form 12 November 2002; accepted 12 November 2002

\begin{abstract}
Considerable crustal thickness variations are inferred along Cayman Trough, a slow-spreading ocean basin in the Caribbean Sea, from modeling of the gravity field. The crust to a distance of $50 \mathrm{~km}$ from the spreading center is only $2-3 \mathrm{~km}$ thick in agreement with dredge and dive results. Crustal thickness increases to $\sim 5.5 \mathrm{~km}$ at distances between 100 and $430 \mathrm{~km}$ west of the spreading center and to $3.5-6 \mathrm{~km}$ at distances between 60 and $370 \mathrm{~km}$ east of the spreading center. The increase in thickness is interpreted to represent serpentinization of the uppermost mantle lithosphere, rather than a true increase in the volume of accreted ocean crust. Serpentinized peridotite rocks have indeed been dredged from the base of escarpments of oceanic crust rocks in Cayman Trough. Laboratory-measured density and P-wave speed of peridotite with $40-50 \%$ serpentine are similar to the observed speed in published refraction results and to the inferred density from the model. Crustal thickness gradually increases to $7-8 \mathrm{~km}$ at the far ends of the trough partially in areas where sea floor magnetic anomalies were identified. Basement depth becomes gradually shallower starting $250 \mathrm{~km}$ west of the rise and $340 \mathrm{~km}$ east of the rise, in contrast to the predicted trend of increasing depth to basement from cooling models of the oceanic lithosphere. The gradual increase in apparent crustal thickness and the shallowing trend of basement depth are interpreted to indicate that the deep distal parts of Cayman Trough are underlain by highly attenuated crust, not by a continuously accreted oceanic crust.
\end{abstract}

Published by Elsevier Science Ltd.

Keywords: Caribbean plate; Cayman trough; Continental margins; Gravity anomalies; Serpentinized peridotite; Slow spreading

\section{Introduction}

Extreme crustal attenuation during the initial opening of ocean basins (Chian, Keen, Reid, \& Louden, 1995; Whitmarsh et al., 1996) and ultra-slow spreading of midocean ridges (Coakley \& Cochran, 1998; Hosford, 2001; Louden, Osler, Srivastava, \& Keen, 1996), appear to have created unusual crustal structure in many ocean basins. The Cayman Trough in the northwestern Caribbean (Fig. 1) is a narrow ocean basin, where we believe one can observed the complete transition from stretched and rifted continental crust to extremely attenuated crust to 'normal' oceanic crust formed at a very slow spreading rate. The Cayman Trough is about $1200 \mathrm{~km}$ long, $100 \mathrm{~km}$ wide, and $5 \mathrm{~km}$ deep; it is the deepest feature in the Caribbean Sea (Fig. 1). It contains a $\sim 100 \mathrm{~km}$-long slow-spreading ridge between two offset

\footnotetext{
* Corresponding author. Tel.: + 1-508-457-2396; fax: + 1-508-457-2310

E-mail addresses: utenbrink@usgs.gov (U.S. ten Brink),dcoleman@ ife.org (D.F. Coleman), bdillon@usgs.gov (W.P. Dillon).
}

transform faults, the Swan Islands Transform Fault and the Oriente Transform Fault (Fig. 1; Holcombe, Vogt, Matthews, \& Murchinson, 1973). The trough is bounded on the south by the Nicaragua Rise, a shallow submerged platform and on the north by the Cayman Ridge, a narrow sliver that was probably part of the Nicaragua Rise before the opening of the trough. The Nicaragua Rise crust was formed during the Mesozoic and the Eocene in a volcanic arc setting with oceanic arc affinities in the eastern half, and continental arc affinities with possible Paleozoic root in the western half (Pindell \& Barrett, 1990). Cessation of magmatic activity in the Nicaragua Rise about $50 \mathrm{Ma}$ coincided with the collision of the Caribbean plate with the Bahamas platform, the formation of the Cayman Trough, and the initiation of the Middle America Trench (Gordon, Mann, Caceres, \& Flores, 1997; Leroy, Mauffret, Patriat, \& Mercier de Lepinay, 2000; Pindell \& Barrett, 1990).

The transform-ridge-transform system of Cayman Trough accommodates the relative motion between the North American and Caribbean plates (Fig. 1; CAYTROUGH, 


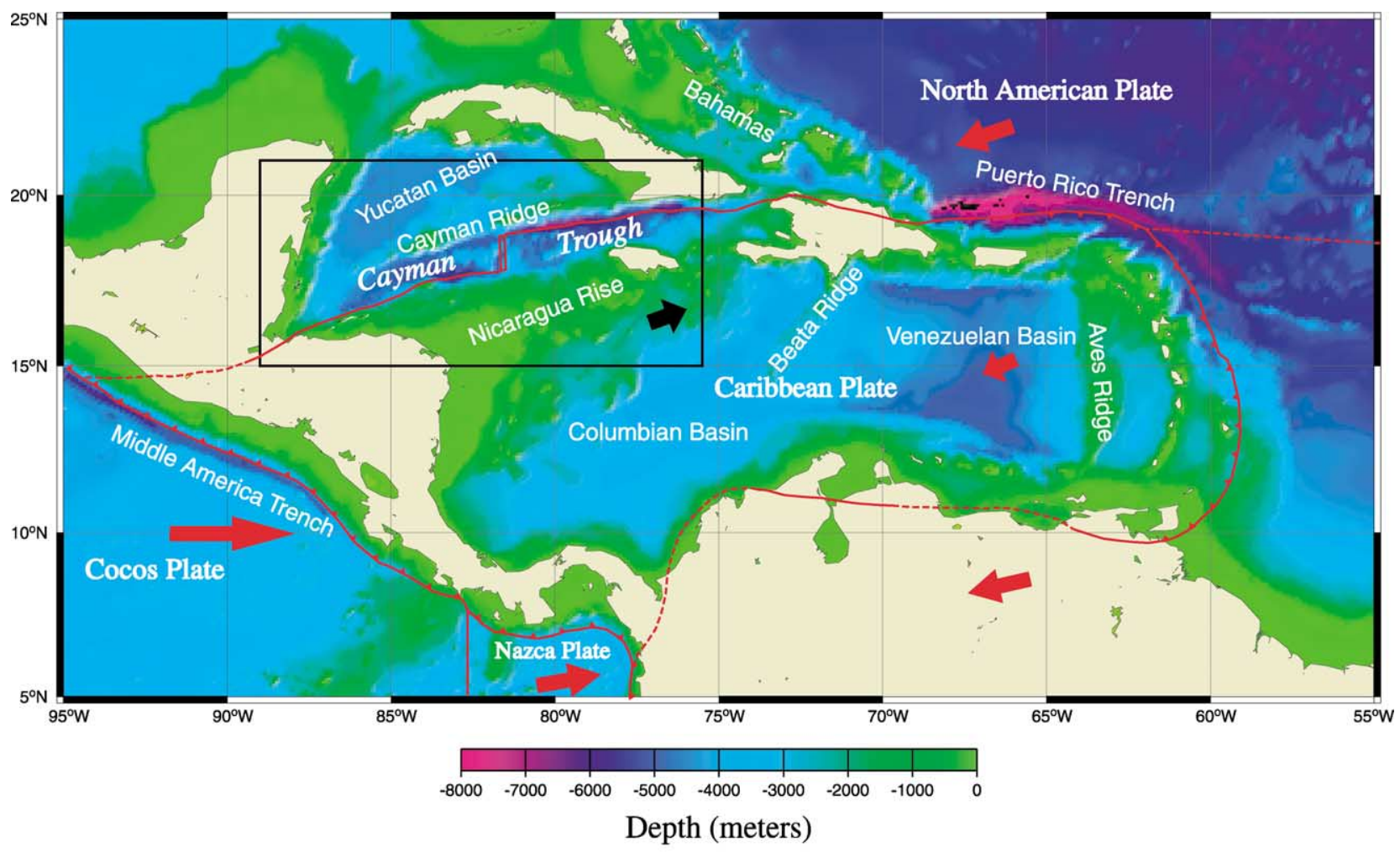

\section{Cayman Trough Neotectonics}

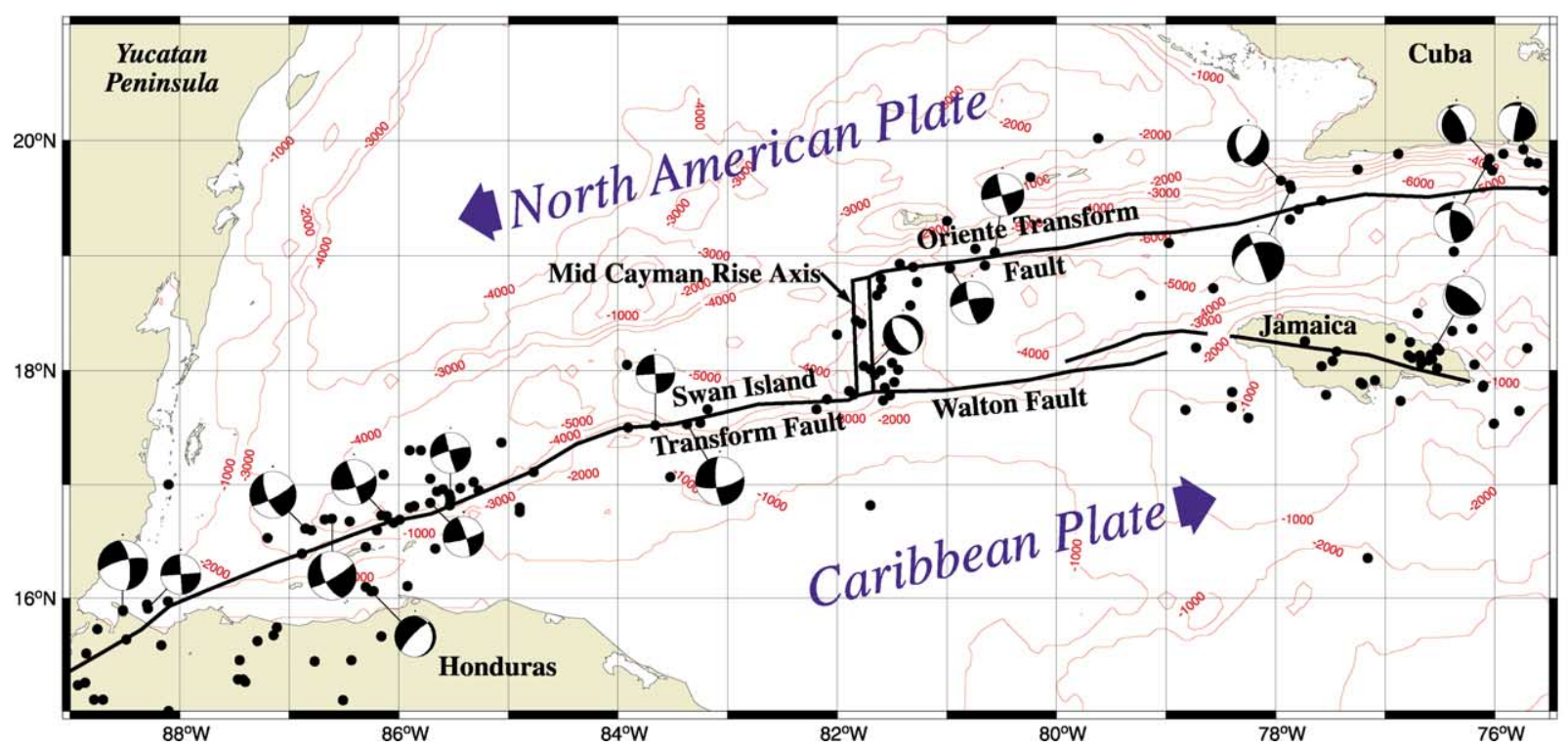

Fig. 1. (a) Major morphologic features of the Caribbean plate and its vicinity. Bathymetric data is from ETOPO-5 database. Region inside box is the study area shown in Figs. 1(b) and 4(a),(b). Tectonic interpretation is modified from Mann, Schubert, and Burke (1990). Black arrow: Caribbean plate motion relative to North America. Red arrows: plate motion vectors relative to a hotspot reference (Gripp \& Gordon, 1990). (b) General bathymetry of Cayman Trough and its vicinity from ETOPO-5 database and the major faults bounding the trough. Earthquake locations are from the NGDCs Preliminary Determination of Epicenters database. The focal mechanism 'beach balls' are from the Harvard Centroid Moment Tensor database.

1979), which is, according to GPS measurements, $20 \mathrm{~mm} / \mathrm{yr}$ in a direction $70^{\circ}$ (Dixon et al., 1998). The predominance of left-lateral strike-slip motion along the transform faults is made evident by focal mechanism solutions of earthquakes
(Fig. 1). The principal stress directions indicated by the focal mechanisms are consistent with previous calculations of relative plate motion determined from earthquake firstmotion studies (Molnar \& Sykes, 1969). These focal 
mechanisms are also consistent with the NUVEL-1 relative plate motion model (DeMets, Gordon, Argus, \& Stein, 1990).

The linear ridges and rough topography of the central Cayman Trough are typical of active spreading centers (Fig. 2). The seafloor morphology near the active transform faults reveals varying structures such as inside-corner highs and transverse ridges. Such features are commonly observed in slow-spreading mid-ocean ridges (Bonatti et al., 1994; Tucholke \& Lin, 1994). Although the topography shows a sea floor spreading grain, the magnetic field in the Cayman Trough is dominated by high-amplitude non-linear anomalies and by high-amplitude transform-parallel anomalies (Fig. 3). The origin of these anomalies is probably post-rift volcanic or tectonic activity. For example, Gainsbourg Ridge, a NE-SW-oriented ridge at $18.3^{\circ} \mathrm{N}$ $80^{\circ} \mathrm{W}$ is an oceanic crust formed at the spreading center (Perfit, 1977), that was later uplifted (Rosencrantz \& Mann, 1991). Seafloor-spreading magnetic anomalies, on the other hand, have low amplitude because of the low latitude of Cayman Trough.

Magnetic anomalies correlated among several east-west lines were used to identify sea floor spreading varying distances from the spreading ridge. Macdonald and Holcombe (1978) interpreted magnetic anomalies to distances of 95 and $140 \mathrm{~km}$ east and west of the spreading center, respectively, as showing nearly symmetrical spreading with total opening rate of $20 \mathrm{~mm} / \mathrm{yr}$ between 0 and $2.4 \mathrm{Ma}$ and $40 \mathrm{~mm} / \mathrm{yr}$ between $2.4-6 \mathrm{Ma}$ (east) and 2.48.3 Ma (west). Rosencrantz, Ross, and Sclater (1988) used magnetic anomalies as well as basement depth-age relationship from subsidence curves that accounted for lateral cooling of the narrow trough, to suggest a total opening of $15 \mathrm{~mm} / \mathrm{yr}$ between 0 and 25-30 Ma, a distance of 180 and $250 \mathrm{~km}$ east and west of the spreading center, respectively. They proposed a rate of $\sim 27 \mathrm{~mm} / \mathrm{yr}$ between 30 and $45 \mathrm{Ma}$ out to a distance of $470 \mathrm{~km}$ from the spreading center. Rosencrantz et al. (1988) also noted the asymmetric subsidence in the region proximal to the spreading center, which could be fit with asymmetric spreading rate of $6-7.5$ and $8-10 \mathrm{~mm} / \mathrm{yr}$, east and west of the spreading center, respectively. Based on magnetic anomalies Leroy et al. (2000) proposed symmetric spreading with total opening of $17 \mathrm{~mm} / \mathrm{yr}$ between 0 and $20 \mathrm{Ma}$ (a distance of $170 \mathrm{~km}$ ), total opening of $20 \mathrm{~mm} / \mathrm{yr}$ between 26 and $42 \mathrm{Ma}$ (to a distance of $390 \mathrm{~km}$ ), and $15 \mathrm{~mm} / \mathrm{yr}$ between 42 and $49 \mathrm{Ma}$ (a distance of $440 \mathrm{~km}$ ).

Early gravity studies in the Cayman Trough were based on sparse shiptrack profiles and limited seismic refraction data. Bowin (1968) constructed a cross section from the Yucatan Basin to the Nicaraguan Rise, crossing the eastern part of the Cayman Trough. Dillon, Vedder, and Graf (1972) presented a similar section crossing the western part of the trough. Both studies reveal large negative free-air anomalies across the trough and moderate positive anomalies across the bounding ridge and rise, that were modeled by thin crust within the trough, and thicker crust to the north and south. In this paper, we present the results of a gravity model along the trough parallel to the extension direction. We discuss the implications of the model to the processes of extreme extension in a slow-spreading mid-ocean ridge.

\section{Gravity data analysis}

Free-air gravity anomaly data from ocean basins can be obtained by satellite altimetry and shipboard gravimetry. We have utilized both types of data to generate two free-air gravity anomaly maps of the central Cayman Trough (Fig. 4(a) and (b)). Comparing the two maps reveals many similarities and differences (Fig. 4(c)) that can be explained by the quality of the individual data sets.

\subsection{Satellite gravity}

Satellite gravity data is collected by a radar altimeter mounted aboard an earth-orbiting satellite. The altimeter measures sea surface elevation with high precision along its orbit path. The altimeter also tracks fixed stations, which have surveyed locations and elevations, so that all data are referenced to a standard level. The internally consistent sealevel data are directly correlated to geoid height anomalies, which represent deviations of the earth's geoid from the reference ellipsoid. The slope of the geoid at a given location is used to calculate the vertical gravity gradient, which is integrated to produce a free-air gravity anomaly for that location. Localized variance is reduced by averaging several exact-repeat orbits of the satellite. This procedure has been performed using recently declassified satellite altimetry data from ERS-1 (European Space Agency), Topex (US/France Cooperative), and Geosat (US Navy) to produce a global free-air gravity anomaly grid (Sandwell \& Smith, 1997).

A sub region of the Sandwell and Smith gravity grid was extracted and resampled with a spatial resolution of 1-min (1 nautical mile) to produce the satellite free-air gravity map of Cayman Trough (Fig. 4(a)). Large negative anomalies occur along the transform faults and at the deep nodal basins at the ends of the rift axis. Large positive anomalies occur over small seamounts and islands and along the transformparallel (transverse) ridges. These anomalies correlate to prominent bathymetric features in the region (Fig. 1(b) and 2).

\subsection{Shipboard gravimetry}

Compared to satellite data, shipboard data typically have higher resolution in well-studied areas, but provide much less overall coverage. The accuracy of a free-air gravity anomaly map from shipboard data depends on the quality of the ship's navigation and other such variables as corrections for gravimeter drift, meter calibration, 


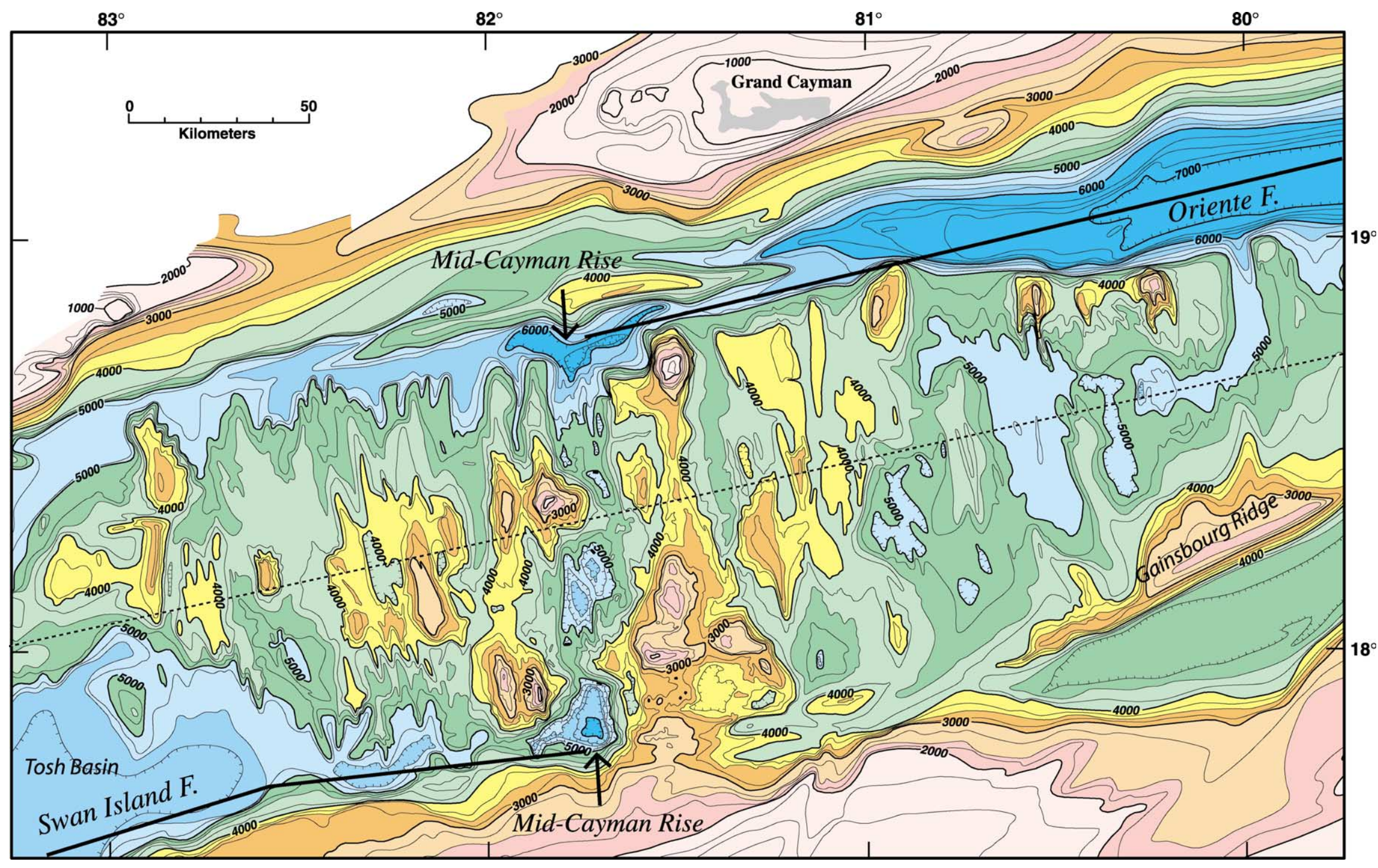

Fig. 2. Bathymetry of central Cayman Trough adapted from Jacobs et al. (1989). Contour interval: $250 \mathrm{~m}$. Dotted line: location of gravity transect. 


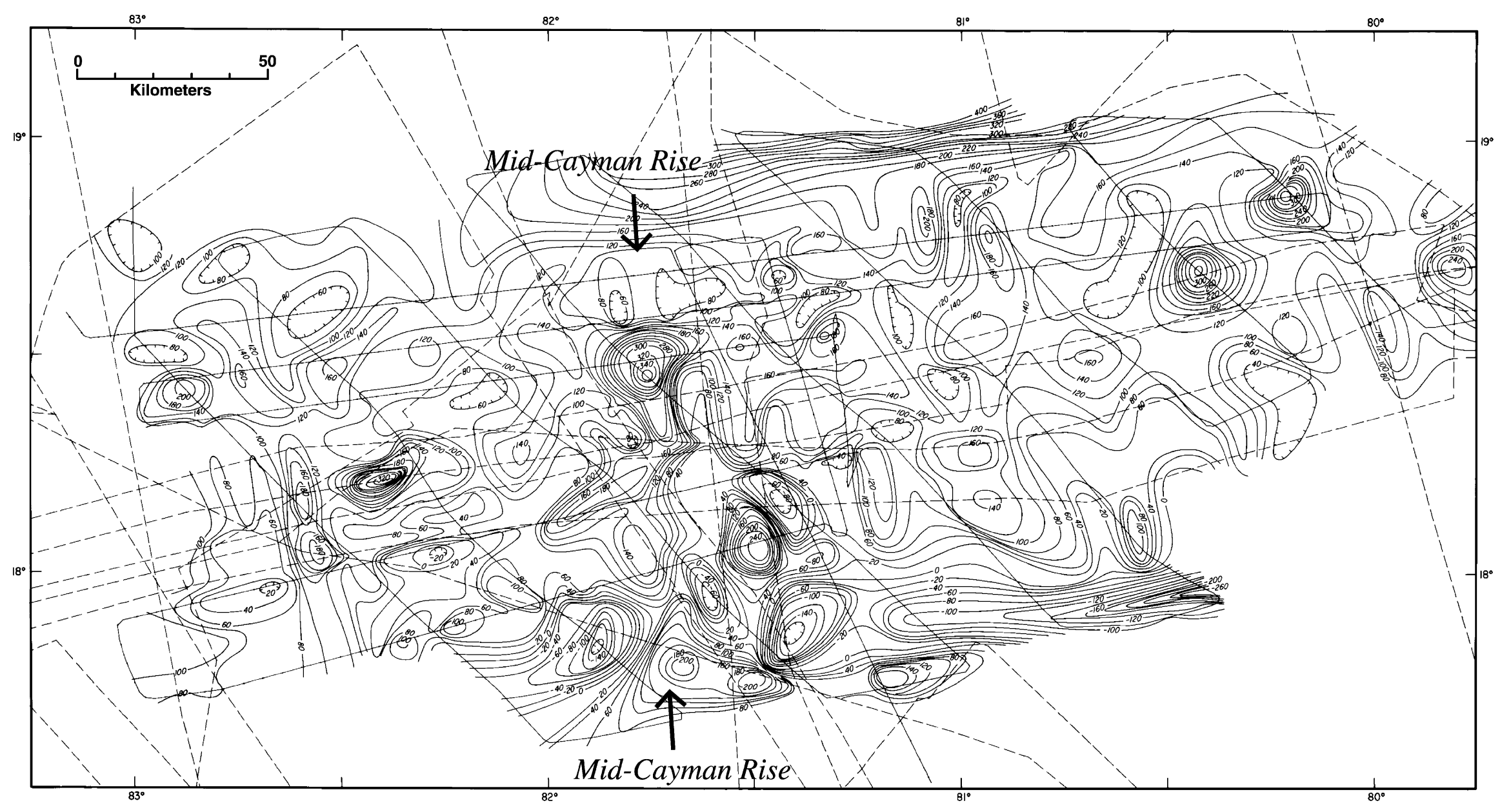

Fig. 3. Magnetic anomaly pattern of the central Cayman Trough adapted from Dillon et al. (1993). Contour interval $20 \mathrm{nT}$. Dashed lines: cruise tracks used to construct the map. 
onshore tie-in errors, and success of efforts to minimize crossing errors to make the data internally consistent.

We have combined data from numerous cruises throughout the Cayman Trough region to generate a comprehensive shipboard gravity data set. The primary sources of data are shipboard gravity data from numerous cruises from 1975 to 1989 (extracted from NGDCs Geodas CD-ROM); data from several USGS cruises of the $R / V$ Starella from the mid-1980s; and both marine and land gravity anomaly data from a database maintained by the Woods Hole Oceanographic Institution (Bowin, 1995, personal communication). The data from
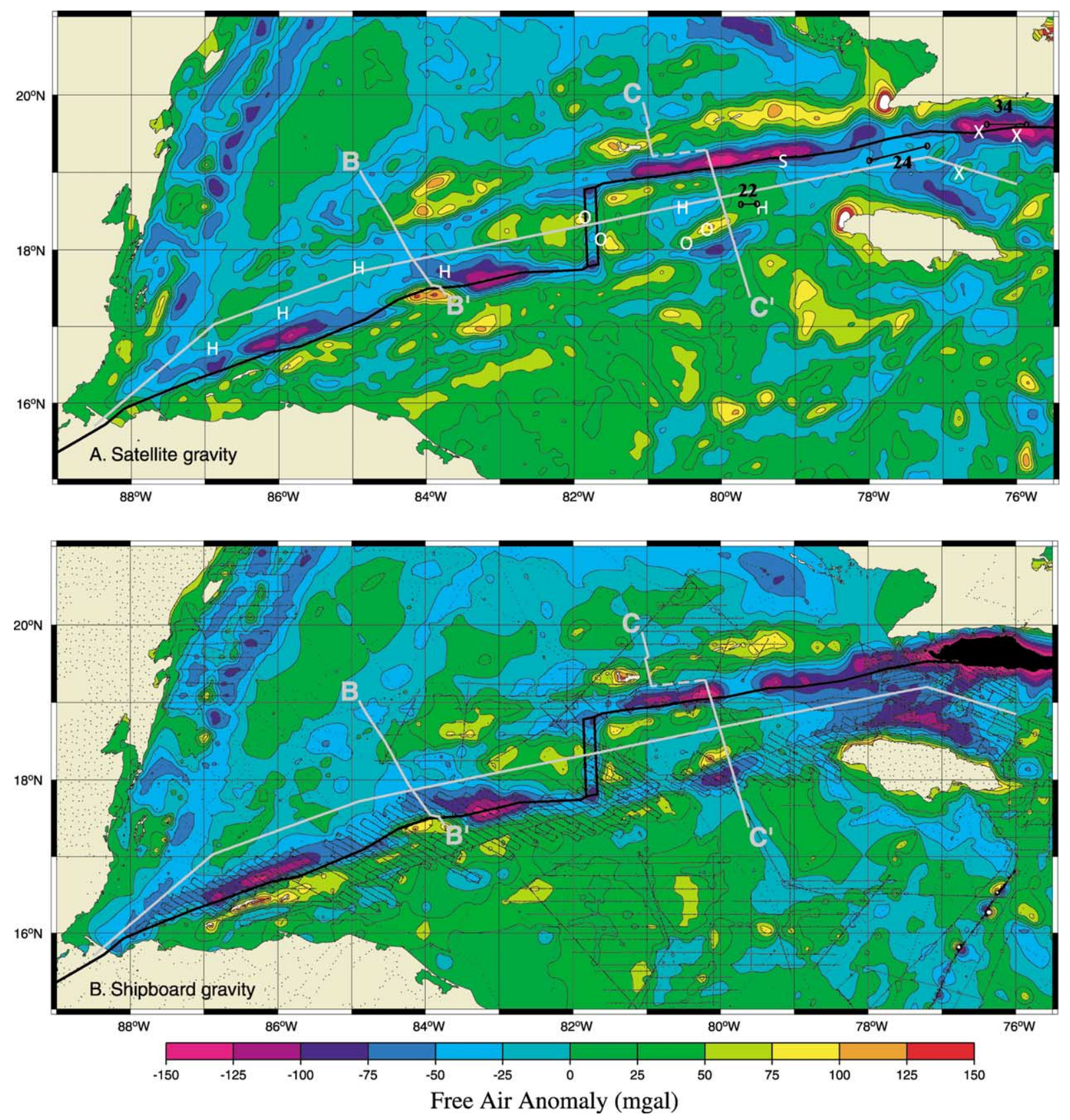

Fig. 4. (a) Free-air gravity anomaly map of the central Cayman Trough derived from satellite altimetry data (Sandwell and Smith, 1997). Grid spacing is 1 min. Contour interval is $10 \mathrm{mGal}$. The locations of the east-west profile along Cayman Trough in Figs. 4(c) and 5 and of profiles B- $\mathrm{B}^{\prime}$, and $\mathrm{C}-\mathrm{C}^{\prime}$ in Fig. $4(\mathrm{c})$ are shown as gray lines. Heavy black lines: Caribbean-North America plate boundary. O, S, and X: locations where rocks with oceanic crust affinity, serpentinized peridotite, and continental crust affinity were dredged, respectively (Perfit and Heezen, 1978). H: locations of heat flow measurements shown in Fig. 8. Numbered lines with open circles are locations of two-ship reversed seismic refraction profiles of Ewing et al. (1960). (b) Free-air gravity anomaly map of the central Cayman Trough from shipboard gravity data. Tracklines and individual points that were used to create the map are shown as thin lines and dots. Heavy lines are as in Fig. 4(a). The data were gridded at 1-min blocks. See text for further details about the processing. (c) Comparison between satellite (solid line) and shipboard (short-dashed line) free-air gravity anomalies derived from their respective gridded data sets along the profiles shown in Fig. 4(a) and (b). The actual shipboard gravity measurements along profiles $\mathrm{B}-\mathrm{B}^{\prime}$ and $\mathrm{C}-\mathrm{C}^{\prime}$ (long-dashed lines) are shown for comparison. The origin in profiles $\mathrm{B}-\mathrm{B}^{\prime}$ and $\mathrm{C}-\mathrm{C}^{\prime}$ is located at their crossings with the east-west profile. 

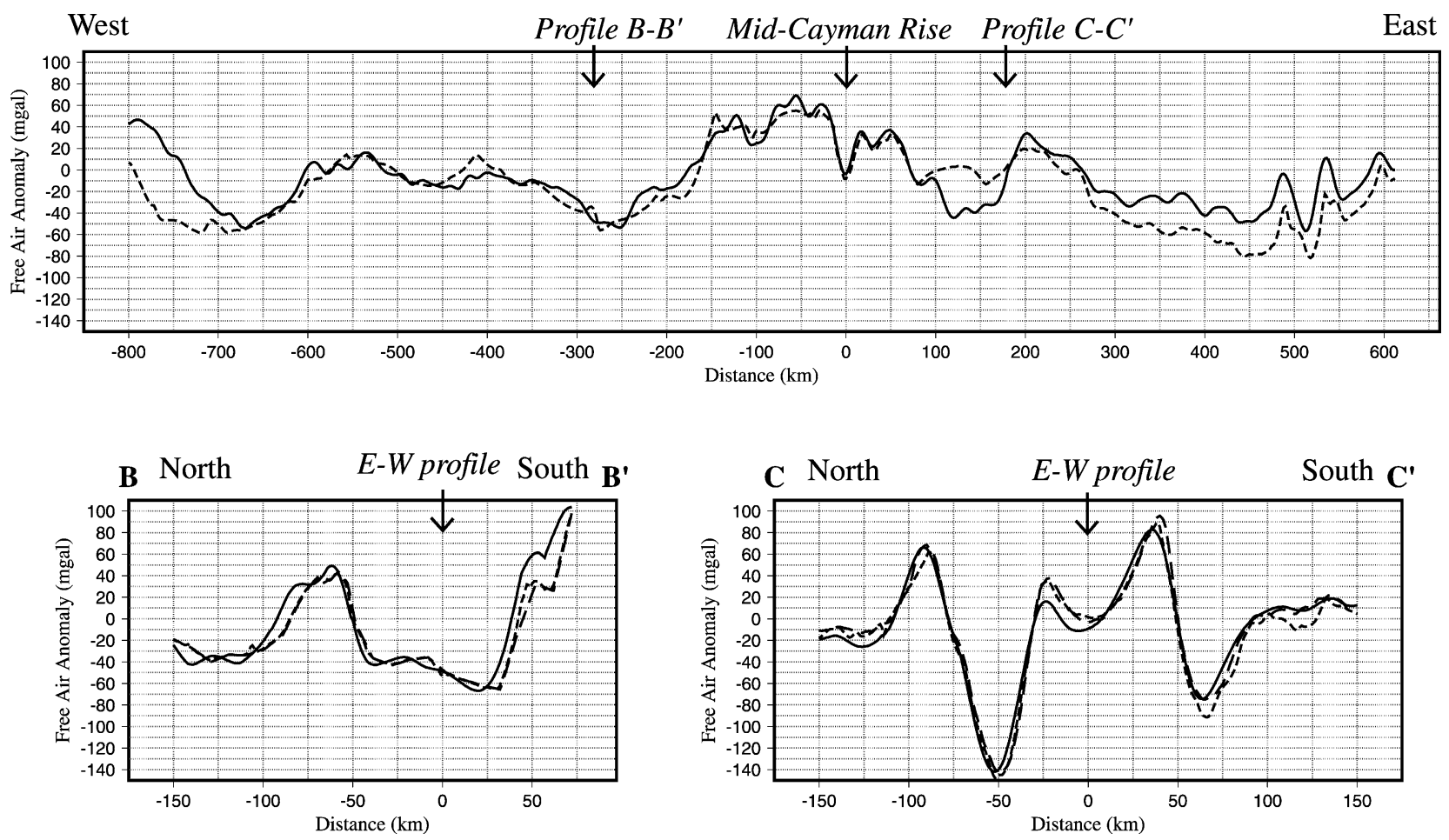

Fig. 4 (continued)

NGDC were corrected for crossover errors using a suite of programs designed for this purpose (Wessel, 1989). Data from the other cruises were either missing important navigation information or did not cross lines from other data sets, so crossover errors were not computed. Inconsistencies between the crossover-corrected data set and the other data sets were found to be minimal, however.

We combined the three gravity data sets into a single coherent and internally-consistent data set, which was median-filtered and gridded using an adjustable-tension continuous-curvature gridding algorithm that interpolates using cubic splines (Smith \& Wessel, 1991). A subset of this grid was extracted and contoured to produce a shipboard free-air gravity anomaly map for the Cayman Trough (Fig. 4(b)). Several errors in the shipboard gravity grid persist as is evident, for example, by the spurious anomalies along a shiptrack in the southeastern corner of the study area (Fig. 4(b)).

\subsection{Comparison of gravity data}

Shipboard marine gravity measurements are made much more frequently in space than satellite altitude measurements. However, exact-repeat orbits of the satellite increases the spatial resolution along track, and the rotating Earth beneath the satellite's orbit, provides two-dimensional (2D) coverage. Shipboard measurements are, in contrast, denser along track, but absent between tracks. Neumann and Forsyth (1993) have shown that satellite marine gravity data is only statistically effective at modeling features with a spatial dimension on the order of $25 \mathrm{~km}$ or more. This is similar to a conclusion by Small and Sandwell (1992), who also compared satellite altimetry and marine gravity. Any feature with a shorter wavelength must be modeled using shipboard gravity. For this investigation, where we are examining crustal thickness variation across very large spatial scales, the satellite data is ideal. The wavelengths of the crustal features we are modeling are not smaller than $25 \mathrm{~km}$.

A first-order comparison of the two maps reveals remarkable similarity between the two data sets, despite differences in data collection and processing techniques. A closer examination, however, reveals small- to intermediate-scale discrepancies between the two maps. There are some fine details in the marine gravity map where shiptracks are closely spaced. These details are much finer than the resolution necessary for our modeling, so this observation is not critical. The largest differences between the two maps occur where there is a lack of shipboard data. The shipboard gravity data in the northeastern corner of the study area between Cuba and Jamaica is consistently more negative than the satellite data, which we attribute to poor marine gravity data corrections during one particular cruise that provided most of the data in this region.

To quantitatively compare the different data sets, we extracted three gravity profiles from each grid, an east-west profile along Cayman Trough for which there is no coincident shipboard gravity profile and two north-south profiles (B-B ${ }^{\prime}$ and $\mathrm{C}-\mathrm{C}^{\prime}$ in Fig. 4(a) and (b)) that coincide 
with actual shiptrack profiles. Discrepancies as large as $25 \mathrm{mGal}$ are observed in regions where there is sparse shipboard data, but differences are less than $\sim 10 \mathrm{mGal}$ in regions where there is sufficient ship control, so we conclude that the accuracy of the satellite data can be trusted to this precision. This paper focuses on the regional variations of gravity anomaly along the trough, and therefore we use the satellite gravity data, which is more internally consistent to construct crustal models of the Cayman Trough.

\section{Gravity modeling}

An east-west profile along Cayman Trough was selected to coincide with several seismic reflection profiles from the region that provide bathymetry and sediment thickness variations along the trough for the model (Figs. 4 and 5). A seismic reflection line from an $R / V$ Wilkes cruise in 1973 (see Ladd, Holcombe, Westbrook, \& Edgar, 1990; Fig. 1, profile $\mathrm{B}-\mathrm{B}^{\prime}$ for details) was used as a starting point because it represents the longest and most detailed profile through the trough. Sediment thicknesses and depths were readily interpreted and extracted from the profile. Depth to basement could not be positively identified along the western portion of seismic line, so we used a different seismic line to fill in the gap (Rosencrantz \& Sclater, 1986; Fig. 4, UTIG line CT-1). A small portion between the two lines needed to be interpolated. The profile was bent at the eastern end to maintain maximum distance from the edges of the basin and on the western end to stay at the center of the gravity low. Sediment thickness at the far western end of the line was estimated as $\sim 3 \mathrm{~km}$ based on well data from the Honduras margin (Dillon \& Vedder, 1973). Bathymetric data for this region was extracted from a map compiled by Dillon and
Vedder (1973). Bathymetric and sediment thickness details for the far eastern end of the line were obtained from recent maps of the region between Cuba and Jamaica based on seismic reflection data (Leroy, Mercier de Lepinay, Mauffret, \& Pubellier, 1996; Figs. 4-7). Standard densities were chosen for water $\left(1030 \mathrm{~kg} / \mathrm{m}^{3}\right)$, sediment $(2000 \mathrm{~kg} /$ $\left.\mathrm{m}^{3}\right)$, and rocks comprising the upper crust $\left(2670 \mathrm{~kg} / \mathrm{m}^{3}\right)$. We chose these densities based on previous data and rock dredge samples from various parts of the trough (Perfit \& Heezen, 1978). Standard densities were also chosen for the lower crust and upper mantle densities, $2900 \mathrm{~kg} / \mathrm{m}^{3}$ and $3320 \mathrm{~kg} / \mathrm{m}^{3}$, respectively.

We divided the crust along a horizontal interface, because a horizontal interface adds a constant value to the entire calculated anomaly. A constant shift is commonly applied to regional gravity models, where the purpose of the models is to identify density variations within the region. By dividing the crust with a horizontal interface, we effectively consider the gravity anomaly to arise from the density contrasts at the sediment-water interface $\left(970 \mathrm{~kg} / \mathrm{m}^{3}\right)$, basement $\left(1640 \mathrm{~kg} / \mathrm{m}^{3}\right.$ or $\left.670 \mathrm{~kg} / \mathrm{m}^{3}\right)$ and at the Moho $\left(420 \mathrm{~kg} / \mathrm{m}^{3}\right)$. We chose not to add an additional interface mimicking the top of the crust, as is sometimes done for layered ocean crust, because this adds another degree of uncertainty to the model and assumes a priori that the crust is oceanic. Presently, our model uses known bathymetry and basement topography to solve for one unknown interface, the Moho. Moreover, Prince and Forsyth (1988) showed that modeling the oceanic crust with a density gradient instead of a constant density changes the calculated anomaly by $3 \%$.

To obtain a starting crustal thickness, we use results from reversed seismic refraction profiles 22E, $22 \mathrm{~W}$ and $24 \mathrm{~W}$ (see Fig. 4 for location) of Ewing, Antoine, and Ewing (1960) which give a total crustal and sediment thickness of $\sim 5.5 \mathrm{~km}$. The calculated anomaly from this model

Fig. 5. (a) Top: observed and calculated gravity along an east-west profile shown in Fig. 4. Observed profile was derived from the gridded satellite data set of Fig. 4(a). Bottom: model used to calculate the gravity anomaly. Model assumes a constant mantle density and a constant crustal thickness of $5.5 \mathrm{~km}$ along the entire Cayman Trough. Average crustal thickness is based on seismic refraction data (Ewing et al., 1960, profiles 22 and 24W, see Fig. 4(a) for location). Origin is the spreading center. Bathymetry and sediment thickness data were extracted from a variety of sources listed in the text. The horizontal upper/lower crustal boundary contributes a constant shift to the calculated gravity, thus reducing one unknown parameter in the modeling. See text for further discussion. Note the close match for the regions on either side of central part of the basin, but a poor fit elsewhere. (b) Gravity calculated by including upper mantle density variations resulting from the cooling of a narrow ocean basin away from the spreading center. Densities are in $10^{3} \mathrm{~kg} \mathrm{~m}^{-3}$. See text for information on the mantle thermal and density models. The calculated gravity significantly underestimates the observed anomaly near the spreading center. Crustal thickness at the distal edges of the model was adjusted to fit the gravity there. (c) Gravity calculated by the same density model as in (b), but with a 2.5D model instead of the 2D model used in (b). This $2.5 \mathrm{D}$ model assumes that the density model extends to a distance $31 \mathrm{~km}$ on either side of the modeled profile, beyond which the mantle density distribution with depth is similar to that under the far edges of the profile (represented by yellow dashed line). This reflects the thermal structure perpendicular to the trough. See Fig. 6 for the choice of $31 \mathrm{~km}$. The use of a 2.5D model with these parameters substantially improved the fit to the observed gravity. (d) Finer adjustments to the crustal thickness within the deep part of the trough farther improve the fit to the observed gravity. Vertical lines denote crustal thickness determined by seismic refraction models (Ewing et al., 1960), and are plotted at the locations of the stationary recording stations, while the shooting ship was sailing away. See Fig. 4(a) for their locations. Arrows denote the farthest extent of seafloor magnetic anomalies identified by Leroy et al. (2000) and Rosencrantz et al. (1988). Note the thin crust in the vicinity of the spreading center which is in accord with dredging results, thicker crust farther away and a gradual increase in crustal thickness starting at -430 and $+370 \mathrm{~km}$. (e) An alternative model to (d) with an 'intracrustal' interface that mimics the basement. This model explores the possibility that the crust throughout the deep part of the trough is thin (2-3 km) and is underlain by upper mantle serpentinized peridotite (striped region). The fit of this model to the observed gravity is comparable to that of (d). (f) An alternative model to (d) exploring the possibility that the distal parts of the Mid-Cayman Rise $(> \pm 170 \mathrm{~km})$ were formed by extreme crustal attenuation, not organized sea floor spreading. A constant density distribution with depth within the distal deep parts of the trough was used to mimic uniform extension for lack of thermal constraints. This density distribution is similar to that at $\pm 242 \mathrm{~km}$ in (d) and is equivalent to a $27 \mathrm{Myr}$ cooling lithosphere with the parameters used in (d). 


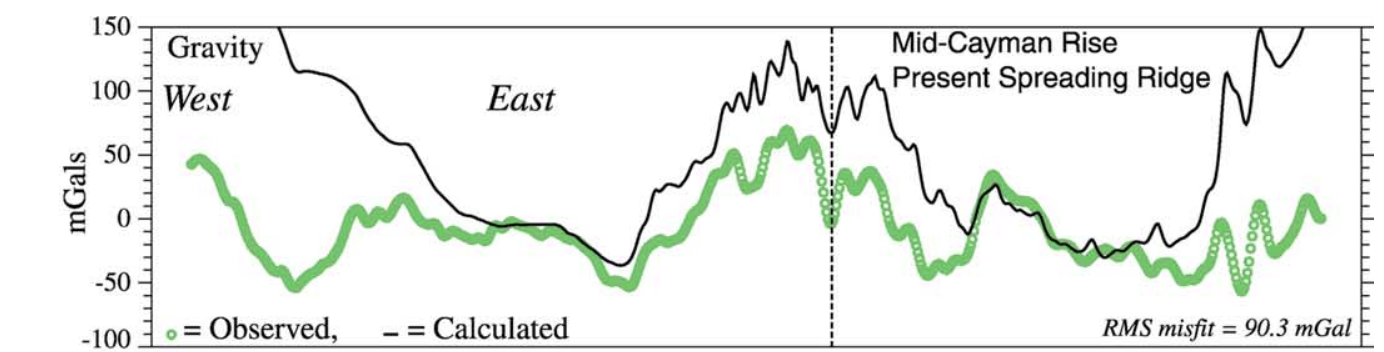

(a)
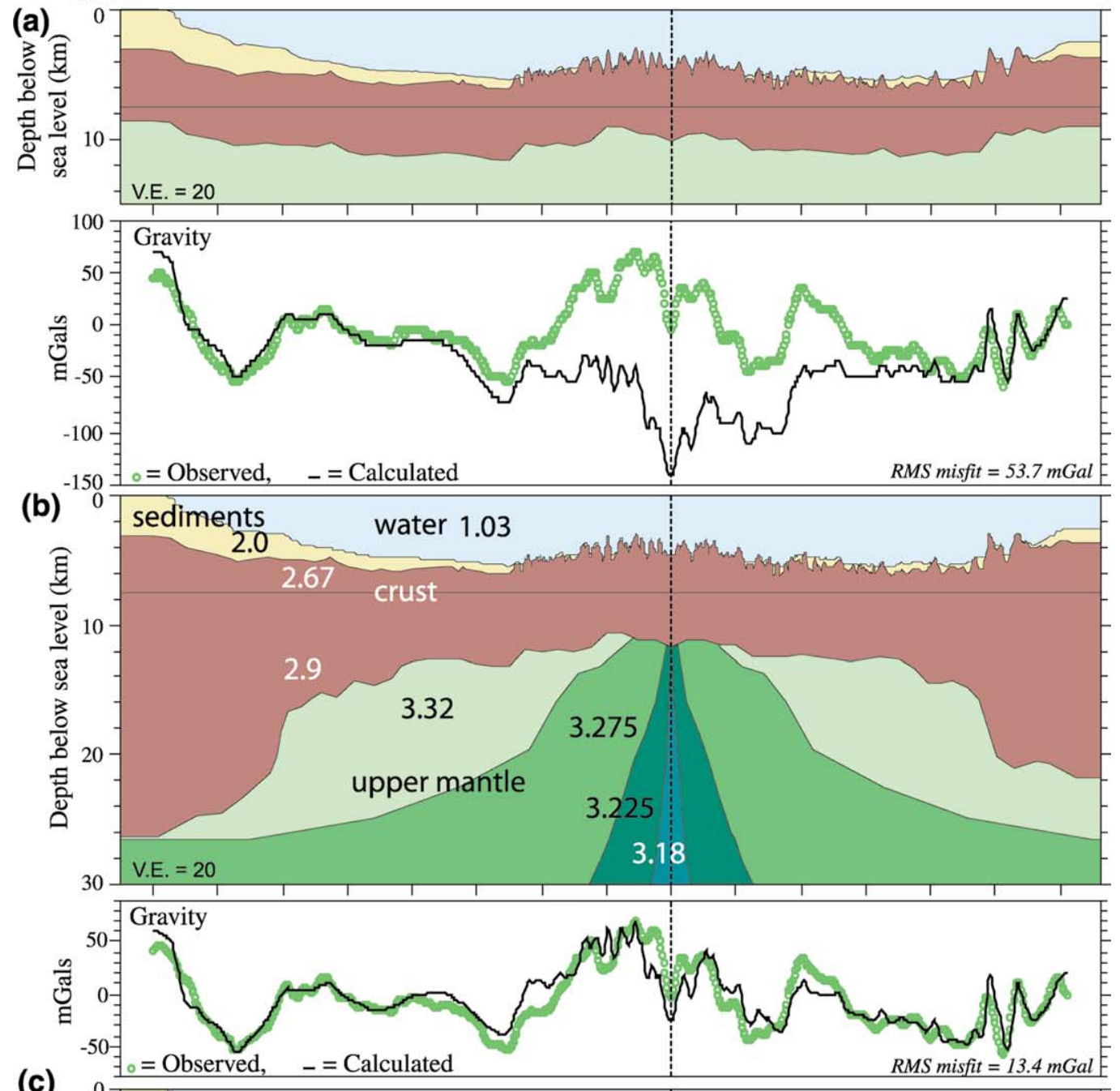

(c)

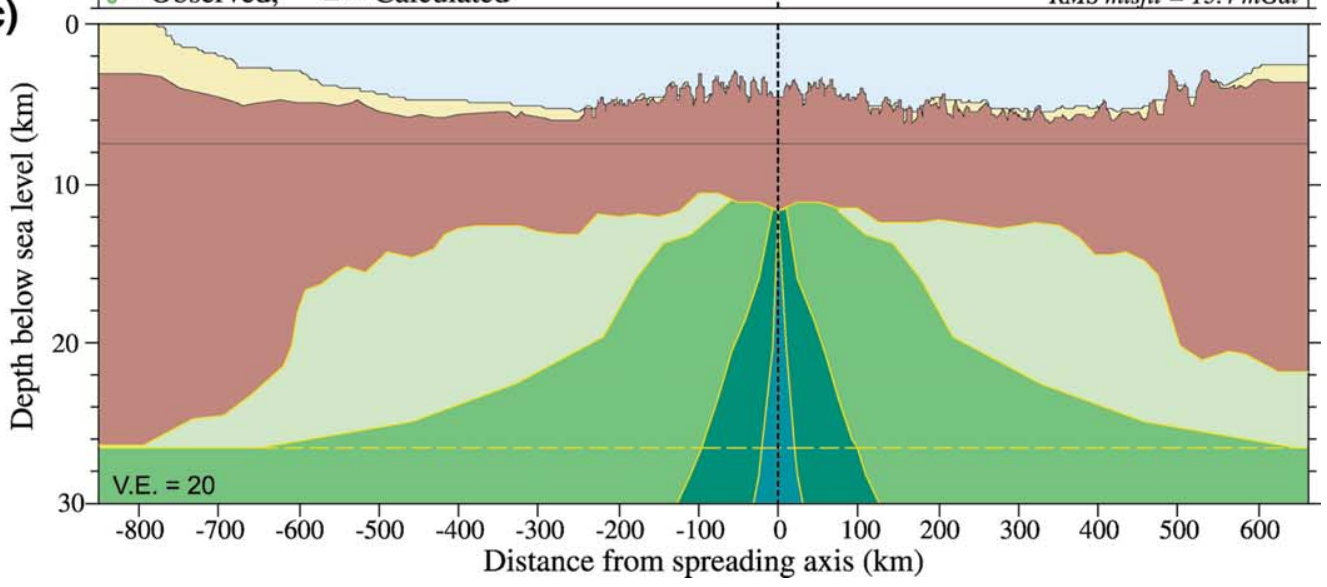



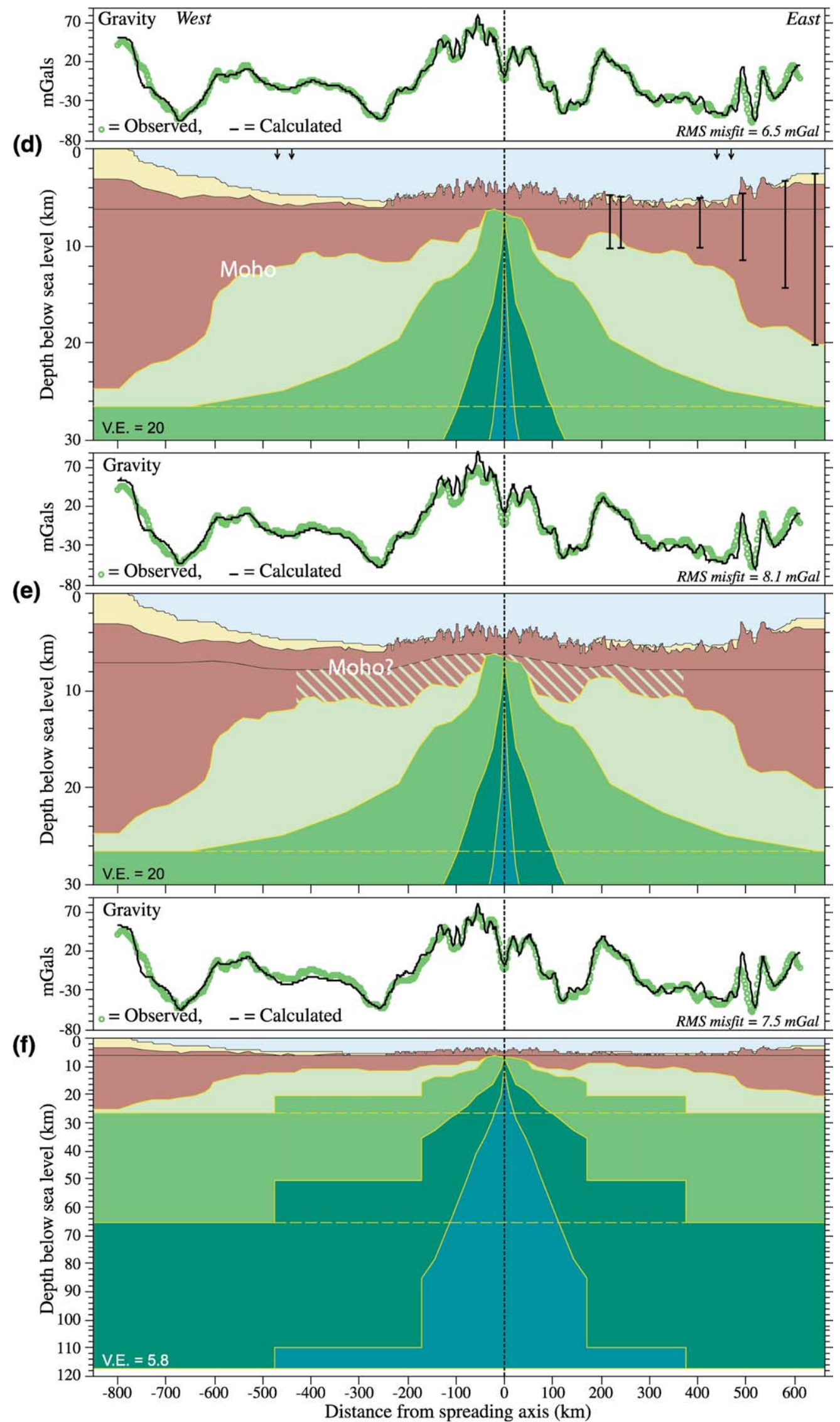

Fig. 5 (continued) 


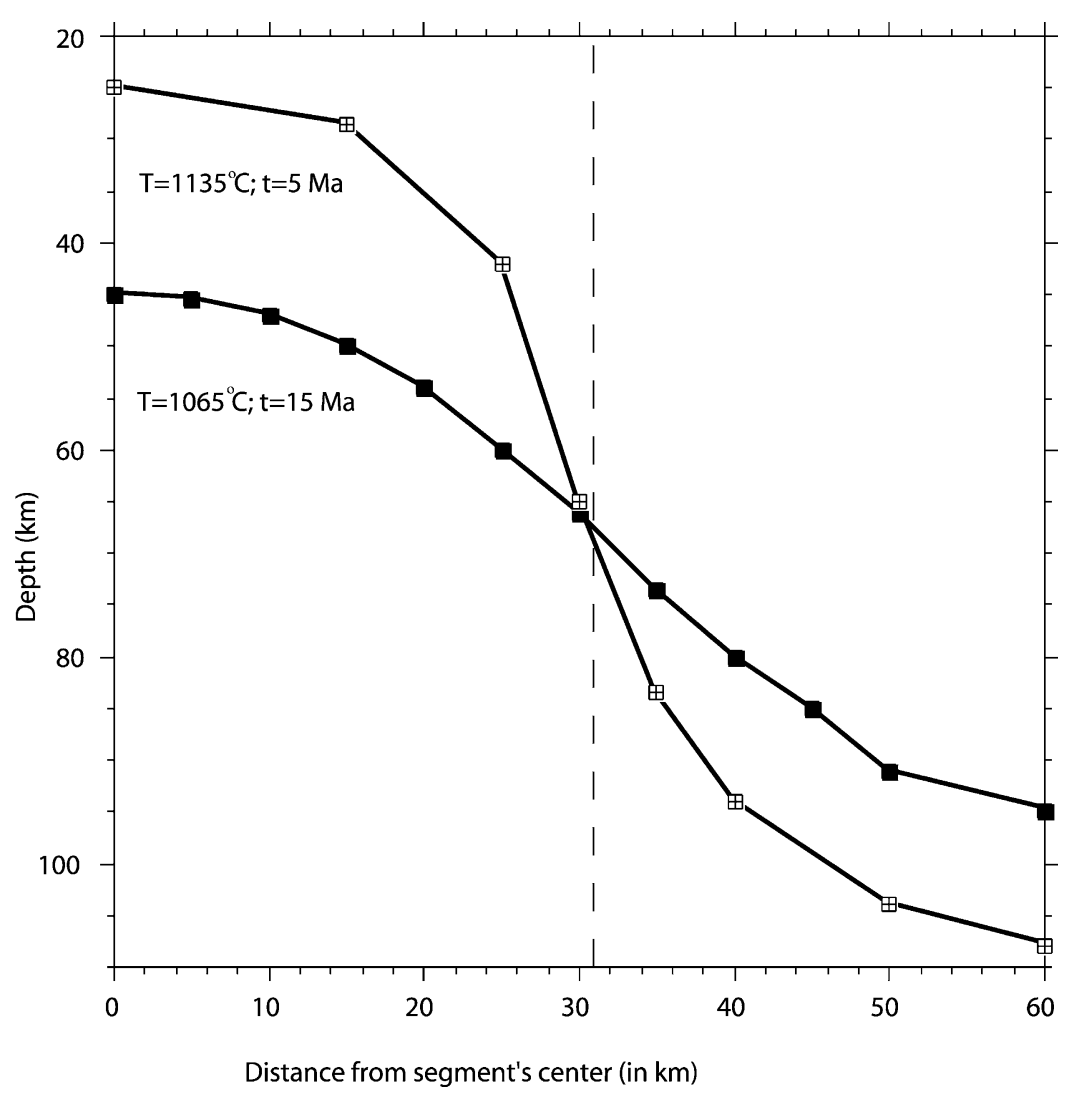

Fig. 6. Depth to a constant temperature as a function of the distance parallel to the spreading center for oceanic lithosphere with ages of 5 and 15 Ma. The origin is at the center of the spreading segment. A cooling plate model for narrow ocean basins (Boerner and Sclater, 1988) was used with values for spreading rates and segment width from Leroy et al. (2000). The rapid depth increase of the isotherms around $31 \mathrm{~km}$ indicates rapid lateral cooling of the lithosphere and was used to estimate the width of the density model in the $2.5 \mathrm{D}$ gravity model of Fig. 5(c)-(f).

(Fig. 5(a)) fits the distal parts of the trough $(280-430 \mathrm{~km}$ and $150-380 \mathrm{~km}$ west and east of the spreading center, respectively) but is higher than the observed anomaly at the trough's ends and at the proximal part of the spreading center.

The model can be improved (Fig. 5(b)) by increasing crustal thickness at the ends of the profile (Honduras and Jamaica), to give a crustal thickness, which approaches that of an island arc. Rocks dredged from the eastern end of the profile are indeed non-oceanic and include granodiorites, tonalities, and chlorite schists (Perfit \& Heezen, 1978).

Because the profile crosses the Mid-Cayman spreading center, cooling of the oceanic lithosphere away from the spreading center leads to variations in mantle density along the profile via thermal expansion. The spreading center is short $(<100 \mathrm{~km})$; hence a $2 \mathrm{D}$ cooling model should be considered. We use the analytic expression for a 2D lithospheric cooling given by Boerner and Sclater (1988) and their parameters to calculate the temperatures under the profile. The opening rates of Leroy et al. (2000) (see in Section 1) are used to convert time to distance along the profile. For the length of the spreading center, we follow Leroy et al. (2000) in modeling an $80 \mathrm{~km}$ long spreading center between 0 and $21 \mathrm{Ma}$ and a-50-km-long center for earlier times. The temperature field is converted to a density field using a coefficient of thermal expansion of $3.28 \times 10^{-5}{ }^{\circ} \mathrm{C}^{-1}$ and the density field is contoured along isodensity lines of 3200,3250 , and $3300 \mathrm{~kg} / \mathrm{m}^{3}$. The isodensity lines serve as the boundaries between four layers within the mantle having densities of $3180,3225,3275$, and $3320 \mathrm{~kg} / \mathrm{m}^{3}$ down to a depth of $125 \mathrm{~km}$ below the seafloor. The lower mantle density due to elevated mantle temperatures under the spreading center, results in a broad $(\sim 600 \mathrm{~km})$ calculated gravity low relative to the observed gravity profile.

The gravity model so far has been strictly 2D. However, because the spreading center is bounded on its sides by a non-oceanic lithosphere, the region of elevated temperatures and reduced density within the upper mantle is expected to have a finite width. Using the 2D lithosphere-cooling model, we find that the thermal anomaly due to seafloor spreading decays rapidly at about $31 \mathrm{~km}$ away from the center of the spreading segment (Fig. 6). We therefore use a $2 \frac{1}{2}$ dimension gravity model in which the density of the mantle lithosphere perpendicular to the profile at distances larger than $31 \mathrm{~km}$ is the same as the density at the far edges of the profile (at $600 \mathrm{~km}$ ). The same distance perpendicular 


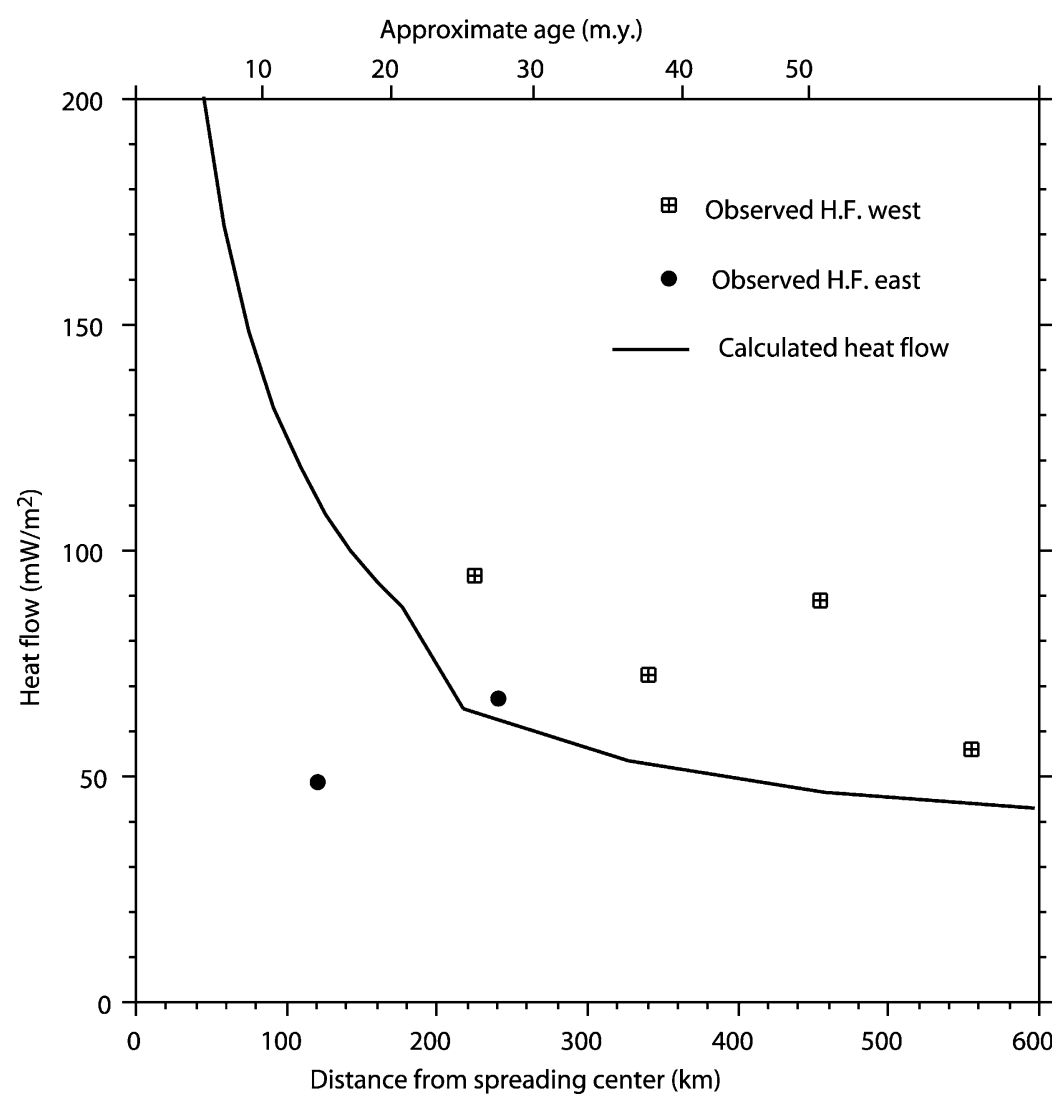

Fig. 7. Observed heat flow in Cayman Trough as a function of distance from the spreading center (from Rosencrantz et al., 1988) and calculated heat flow using Boerner and Sclater (1988) model for narrow ocean basins and values for spreading rates and segment width from Leroy et al. (2000). See Fig. 4 for locations of observations. Four additional observations (Rosencrantz et al., 1988) are not included because of their Proximity to the Oriente Fracture Zone. The step in the calculated anomaly is due to the changes in the half spreading rate from 8.5 to $10 \mathrm{~mm} / \mathrm{yr}$ and in segment width from 80 to $50 \mathrm{~km}$ between 21 and $25 \mathrm{Ma}$ proposed by Leroy et al. (2000).

to the profile is also used for the 50-km-long spreading center at the more distal parts of the model, although this is perhaps an overestimate. The inclusion of this effect results in a considerable improvement to the fit between the calculated and observed anomaly (Fig. 5(c)) even though the crust and mantle structure along the trough axis is identical.

Finally, we modify the crust-mantle interface (Fig. 5(d)) to improve the fit between the calculated and observed gravity anomaly. The final model was compared to crustal thickness determinations from seismic refraction data and the match is generally good. One should bear in mind, however, that these early refraction data consisted of sparse observations, which often made it difficult to correlate arrival branches. In addition, the analysis method consisted of one-dimensional (1D) slope-interface method whereas the crustal thickness appears to increase at stations 24 and 34 .

\section{Results}

Results from the final model calculation (Fig. 5(d)) indicate that the far eastern and far western ends of the model have the largest crustal thicknesses (17$22 \mathrm{~km}$ ). The crust beneath the Honduras (west) end of the trough is thicker than crust beneath the Cuban/Jamaican (east) end, as would be expected, due to the nature of continental arc crust versus island arc crust (Pindell \& Barrett, 1990). The crystalline crust west of Mid-Cayman Rise between 100 and $430 \mathrm{~km}$ has a relatively constant thickness of $5.5 \mathrm{~km}$, and it increases gradually to $8 \mathrm{~km}$ between 430 and $550 \mathrm{~km}$. Crustal thickness variability east of Mid-Cayman spreading center between 60 and $370 \mathrm{~km}$ is much larger $(3.5-6 \mathrm{~km})$. The crustal thickness increases gradually from 5.5 to $7 \mathrm{~km}$ between 370 and $455 \mathrm{~km}$.

The crust $50 \mathrm{~km}$ on either side of the spreading center is only $2-3 \mathrm{~km}$ thick. From global correlations of oceanic ridge basalt chemistry with axial depth and crustal thickness, Klein and Langmuir (1987) predicted that oceanic crust at Cayman Trough should be very thin, perhaps as low as $3 \mathrm{~km}$. Dredge and dive samples at the base of the axial valley wall, which has a maximum relief of $3 \mathrm{~km}$ (Fig. 2), have yielded serpentinized peridotite, suggesting that the crust is indeed thin (Stroup \& Fox, 1981). Crustal thickness at the extinct Labrador rift, which had a comparable spreading rate to Cayman Trough, is $3-4 \mathrm{~km}$, 


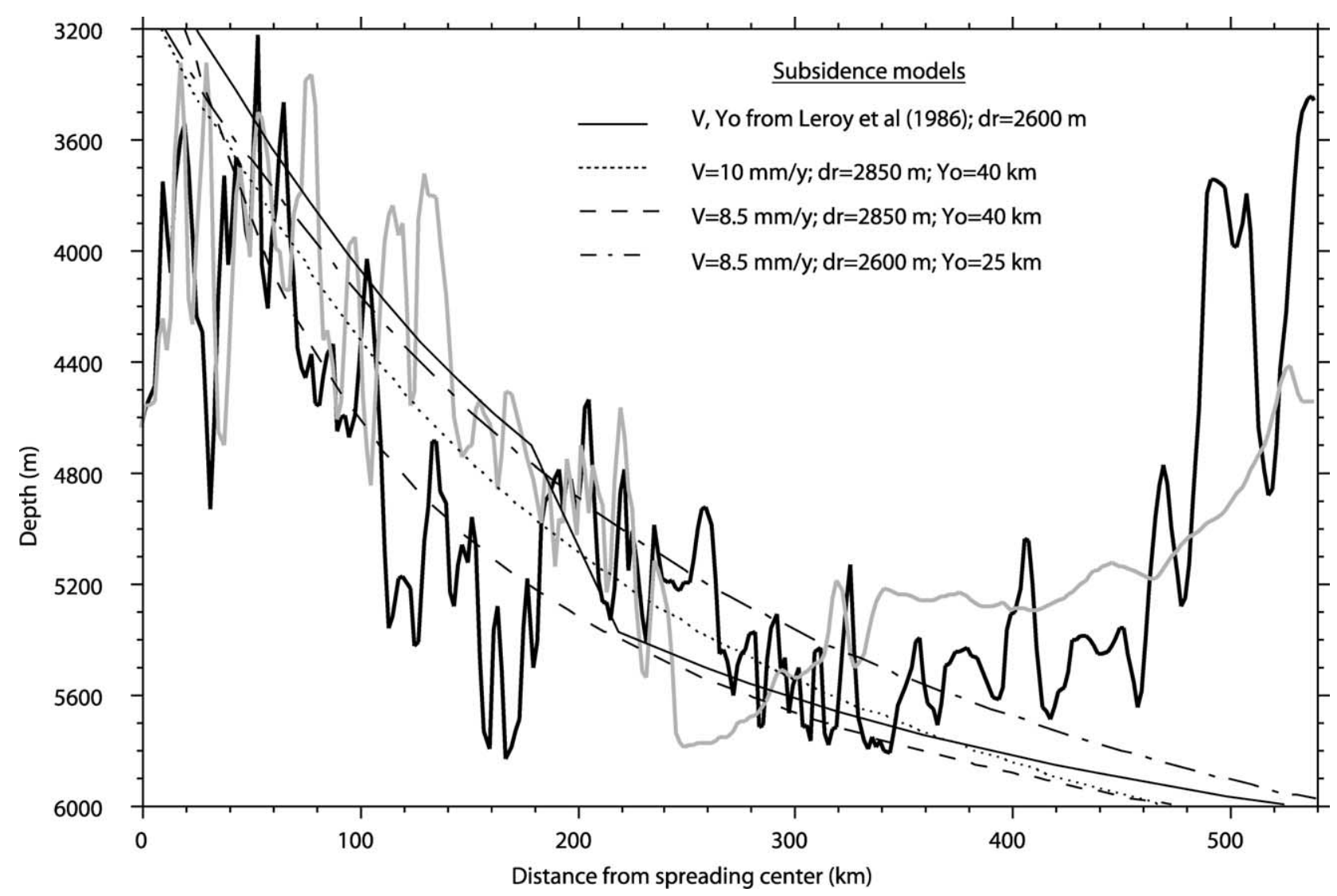

Fig. 8. Depth to basement east (heavy line) and west (gray line) of Mid-Cayman rise as a function of distance from the rise. Depth was corrected for sediment load using the densities of the gravity model. Also shown are curves of calculated depth to basement using Boerner and Sclater (1988) model for narrow ocean basins and various values for zero-age ridge depth, $d_{\mathrm{r}}$, spreading rate, $V$, and segment half width, $Y_{0}$. Note that basement depth decreases beyond $250 \mathrm{~km}$ west of the rise and $340 \mathrm{~km}$ east of the rise, in contrast to the models, which all predict a continuous increase in depth with distance from the rise. The step in the calculated anomaly is due to the changes in the spreading rate and segment width between 21 and 25 Ma proposed by Leroy et al. (2000).

although the thinner crust in the Labrador rift was attributed to post-accretionary extension (Louden et al., 1996).

The gravity profile crosses the spreading center close to what appears to be an offset in the bathymetry of the median valley. This offset may be an artifact of a large constructional feature on the western edge of the median valley, or it may represent a short discontinuity in magma upwelling. If the offset represents a discontinuity in the spreading center, the model may reflect the structure of the discontinuity or of the spreading segment edge. We favor the first interpretation, because the bathymetric ridges immediately to the west of the constructional feature and east of the median valley appear to have continuous trends across Cayman Trough. In addition, the fit between the derived crustal thickness from the gravity profile and that inferred from dredges located away from the offset, indicate that crustal structure along our profile may is representative of Cayman Trough. Finally, there is little information about the total length of the spreading center and about potential discontinuities within it in areas of the trough that are farther from the spreading center and are the focus of the discussion.

\section{Discussion}

\subsection{Serpentinized peridotite underlying a thin crust?}

The crustal thickness variations revealed by the gravity model show thin crust $(2-3 \mathrm{~km})$ to a distance of about $50 \mathrm{~km}$ on either side of the spreading center and much thicker crust (up to $6 \mathrm{~km}$ ) farther away. Yet none of the published magnetic models indicate a change in spreading rate at this distance. We suggest that the thickness variations reflect serpentinization of the uppermost mantle, which acts to lower the seismic velocity and density of the rocks, giving the appearance of a thicker crust. A gravity model with a 5$6 \mathrm{~km}$ thick crust is virtually indistinct from a model with $2-3 \mathrm{~km}$ thick crust and the remaining layer having a lowdensity $\left(\sim 2900 \mathrm{~kg} / \mathrm{m}^{3}\right)$ upper mantle serpentinized peridotite (Fig. 5(e)). Laboratory measurements of serpentinized peridotite with $40-50 \%$ serpentine by volume give a density range of $2800-2900 \mathrm{~kg} / \mathrm{m}^{3}$ and a $\mathrm{P}$ wave velocity range of $6.4-6.7 \mathrm{~km} / \mathrm{s}$ (Christensen, 1966). A lower crust layer with a velocity $6.4-6.6 \mathrm{~km} / \mathrm{s}$ was identified beneath Cayman Trough (Ewing et al., 1960). This velocity range is 
similar to that from laboratory measurements of serpentinized peridotite and is less than a typical 'oceanic layer 3' velocity. One should bear in mind, of course, that Ewing et al. (1960) velocity structure probably has large uncertainties because of the sparse data and the interpretation of the data with a 1D slope-intercept method.

Several other lines of evidence lead us to suggest that part of the so-called crust contains serpentinized peridotite. Dredge samples from Gainsbourg Ridge consist of serpentinized peridotite overlain by gabbro and basalt (Perfit \& Heezen, 1978) with rare earth elemental composition of oceanic crust (Perfit, 1977). Dredges of serpentinized peridotite were also recovered farther east within the trough ( $\mathrm{S}$ in Fig. 4(a)), although they may be affected there by the proximity to the Oriente fracture zone. There are no dredge samples west of the rise. However, heat flow west of the rise is remarkably constant irrespective of distance from the spreading center (Fig. 7), probably indicating continued hydrothermal circulation within the trough.

Paths of fluid flow through the crust and uppermost mantle can be maintained if tectonic activity continues after spreading stopped. A seismic reflection profile north of the eastern tip of Jamaica shows an inclined zone of reflectivity, presumably a fault, extending down $2.5 \mathrm{~s}$ below the sediments (Leroy et al., 1996). Basement and the overlying sediments appear deformed up to the seafloor, indicating continued tectonic activity after the formation of the crust. Using side-scan data, Rosencrantz and Mann (1991) documented recent deformation east and west of MidCayman Rise, which may facilitate continued hydrothermal circulation.

\subsection{Transitional crust in Cayman Trough?}

In light of the difficulty in identifying seafloor magnetic anomalies in the distal parts of the trough and in light of the very slow spreading rate proposed for Cayman Trough, and the evidence for post-spreading tectonic activity, it is unclear how much of the seafloor in the trough was formed by magmatic accretion at the spreading center, and how much represents an extremely attenuated lithosphere by tectonic forces.

Our gravity model (Fig. 5(d)) suggests that crustal thickening starts $430 \mathrm{~km}$ west of Mid-Cayman Rise and $370 \mathrm{~km}$ east of Mid-Cayman Rise. If the change in crustal thickness indicates a transition from an oceanic crust to a highly extended continental crust, then this transition east of Mid-Cayman Rise takes place within the area identified as having seafloor magnetic anomalies. Magnetic anomalies were identified to distances of 470 (Rosencrantz et al., 1988) and $440 \mathrm{~km}$ (Leroy et al., 2000) from the spreading center (Fig. 5(d)).

A plot of depth to basement corrected for sediment loading along the gravity profile reveals peculiar trends (Fig. 8). The basement west of Mid-Cayman Rise begins to shallow $250 \mathrm{~km}$ of the spreading center. Basement east of the rise begins to shallow $340 \mathrm{~km}$ away from the spreading center. These trends are incompatible with the trend predicted by cooling of the lithospheric away from a midocean ridge. Plotted in Fig. 8 is the predicted depth to basement based on the cooling model for a narrow ocean basin with the spreading rates, timing, and ridge width proposed by Leroy et al. (2000), the same parameters that were used to calculate the mantle density in Fig. 5(d) and the heat flow in Fig. 7. Also plotted are other curves with variations on Leroy et al. (2000) parameters, which might fit the observed subsidence. A ubiquitous feature of all the predicted curves is that basement continues to subside to the far edges of the trough some $500 \mathrm{~km}$ away from the spreading center.

Along the western Iberian continental margin, Whitmarsh and Miles (1995) proposed a model for the formation of 'transitional zone' crust that now occupies the floor of the Iberian Abyssal Plain near the ocean-continent transition. Their model suggests that the original continental crust was modified due to tectonic stretching and a propagating rift that impregnated the crust with passively upwelling melt. Based on seismic refraction studies in the same region, Whitmarsh et al. (1996) showed that the preexisting continental crust thins westward to $2 \mathrm{~km}$ and abuts a peridotite ridge. Immediately west of the ridge, oceanic crust is only $\sim 3 \mathrm{~km}$ thick, and it thickens oceanward to a normal thickness $(7 \mathrm{~km})$. A large serpentinized peridotite lens with intermediate $P$ wave speed and density is interpreted to underlie both the thin continental and thin oceanic crust. Seismic velocity and gravity models were integrated with numerical models of melting, and suggest that melt generation, as a function of the amount and duration of stretching, is transient during this early phase of rifting and continental breakup, and that at times, no melt was produced.

Chian et al. (1995) identified 80-km-wide zones of unusual crustal structure on either side of the extinct Labrador Sea spreading center. A thin $(<2 \mathrm{~km})$ low velocity $(4-5 \mathrm{~km} / \mathrm{s})$ layer overlies a $5 \mathrm{~km}$ thick layer with high-velocity and high velocity gradient $(6.4-7.7 \mathrm{~km} / \mathrm{s})$, which is interpreted as serpentinized peridotite, not intrusive gabbros as in normal oceanic crust. The unusual crust changes abruptly to normal thickness oceanic crust closer to the ridge. The transition to a normal oceanic crust also manifests itself in the increase in coherence and strength of magnetic anomalies (Chian et al., 1995). The crust in the transition zone of Labrador Sea may be thinner than a normal oceanic crust because the very slow spreading rate $(0-10 \mathrm{~mm} / \mathrm{yr})$ restricts the volume of the melt produced (Bown \& White, 1994). Alternatively, post-accretionary extension by rotation of fault blocks may explain the abnormally thin crust (Louden et al., 1996). Conversely, the transitional crust may be highly attenuated continental crust, because an observed strong undulating reflector within the transitional crust is interpreted as a detachment separating 
extremely stretched upper continental crust from the underlying serpentinized mantle (Chian et al., 1995).

Similar to Labrador Sea, an increase in the coherence and strength of the magnetic anomalies from the distal parts to the central part is observed in Cayman Trough (Macdonald \& Holcombe, 1978; Rosencrantz et al., 1988) and may indicate a transition from a highly attenuated crust with episodic magmatic accretion to a true ocean crust. The gravity anomaly fits equally well a cooling model with continued subsidence and one with a uniformly stretched lithosphere. Fig. 5(f) shows a model with a uniform extended lithosphere from $170 \mathrm{~km}$ out to the point where the crust begins to thicken. The temperature gradient of this stretched region is equivalent to a $27 \mathrm{Ma}$ oceanic lithosphere or the mantle structure at model $242 \mathrm{~km}$ in Fig. 5(d). Unfortunately, there are no samples in the distal parts of the trough that can help determine the composition of the crust there. Given the narrow dimension of the trough and the slow spreading rate, it is questionable whether the magmatic accretion process is continuous.

\section{Summary}

There has been renewed interest in recent years in the tectono-magmatic processes operating at slow spreading centers because of the recognition that significant portions of the ocean floor might have formed by these processes. Slow spreading of the oceanic lithosphere is presently taking place at the center of Cayman Trough, a narrow basin bounded by continental and island arc lithosphere. Various attempts have been made to use magnetic anomalies to extend the spreading history as far as $49 \mathrm{Ma}$ or $450 \mathrm{~km}$ on either side of the ridge, chiefly to understand Caribbean-North America plate kinematics. For various reasons, however, the identification of magnetic anomalies is equivocal, and other types of observations (seismic, sampling) are sparse. Here we have modeled the crustal structure underlying the trough by matching calculated gravity anomalies to observed measurements along the Cayman Trough, parallel to the opening direction of the basin, and tying the model to available crustal thickness determination from seismic refraction data. Variations in mantle density due to the cooling of the oceanic lithosphere were calculated using the plate model of Boerner and Sclater (1988) that accounts for heat loss perpendicular to the narrow trough. Variations in spreading rates and spreading center length were adopted from Leroy et al. (2000) analysis of seafloor magnetic anomalies, for lack of better constraints. A $2.5 \mathrm{D}$ gravity model was used to account for the denser cooler mantle along the trough walls.

Results show that crustal thickness varies substantially in thickness along the basin. Thinner than normal oceanic crust $(2-3 \mathrm{~km})$ is present in the vicinity of Mid-Cayman rise in agreement with dredge and dive results from the walls of the median valley (Perfit \& Heezen, 1978; Stroup \& Fox, 1981). Farther away from the rise, crustal thickness is $\sim 5.5 \mathrm{~km}$ on the west side between $100-430$ and $3.5-6 \mathrm{~km}$ on the east side between 60 and $370 \mathrm{~km}$ from the rise. The increase in thickness is interpreted to represent serpentinization of the uppermost mantle lithosphere, rather than a true increase in the volume of accreted ocean crust. The $\mathrm{P}$ wave velocity range of serpentinized peridotite is similar to that from seismic refraction data in Cayman Trough, and the density is similar to that of the lower oceanic crust. Serpentinized peridotite is found in many dredge samples east of the rise, the heat flow hardly diminishes with distance west of the rise, and there is evidence for post-spreading tectonic activity. Hence, rigorous hydrothermal circulation may extend to the distal parts of the rise creating a thick layer of serpentinized peridotite.

The apparent crustal thickness gradually increases to 7$8 \mathrm{~km}$ in the distal parts of the rise in regions that in part were interpreted to have sea floor magnetic anomalies. This raises the question of how far from the rise did organized sea floor spreading occur. Cooling models of the oceanic lithosphere, even when taking into account the narrow dimensions of Cayman Trough predict that depth to basement increases with age or with distance from the rise. However, basement depth when corrected for sediment loading becomes gradually shallower starting $250 \mathrm{~km}$ west of the rise and $340 \mathrm{~km}$ east of the rise. This may indicate that parts of the deep distal regions of Cayman Trough are underlain by highly attenuated transitional crust, not by a continuously accreted oceanic crust. Serpentinization of the uppermost mantle and the existence of highly attenuated crust, as we propose here are not unique to Cayman Trough. They have been recognized in other slow spreading ridges such as the Labrador Sea (Chian et al., 1995). However, Cayman Trough is far from mantle plumes and offers a unique opportunity to observe changes over short distances from conjugate continental margins all the way to a slow spreading ridge. More direct observations of crustal thickness and composition in the Cayman Trough are needed to test our interpretations.

\section{Acknowledgements}

We thank Troy Holcombe, NOAA National Geophysical Data Center, for the bathymetry data of the central Cayman Trough, Carl Bowin, Woods Hole Oceanographic Institution for a gravity data set, and Jen Martin for computer and graphical assistance. DFC would like to thank Chris Kincaid and Roger Larson, University of Rhode Island, for their encouragement and support. Discussions with Terence Edgar, Hans Schouten, Allegra Hosford, and Jian Lin, and reviews of an earlier version of this manuscript by Allegra Hosford and Hans Schouten, are gratefully acknowledged. DFC was partly supported by NSF grant EAR-92-19796. 


\section{References}

Boerner, S. T., \& Sclater, J. G. (1988). Approximate solutions for the heat loss in small marginal basins. In J. A. Wright, \& K. E. Louden (Eds.), Handbook of seafloor heat flow (pp. 231-256). Boca Raton, FL: CRC press.

Bonatti, E., Ligi, M., Gasperini, L., Peyve, A., Raznitsin, Y., Chen, Y.J. (1994). Transform migration and vertical tectonics at the Romanche fracture zone, Equatorial Atlantic. Journal of Geophysical Research, 99, 21779-21802.

Bowin, C. (1968). Geophysical study of the Cayman Trough. Journal of Geophysical Research, 73, 5159-5173.

Bown, J. W., \& White, R. S. (1994). Variation with spreading rate of oceanic crustal thickness and geochemistry. Earth and Planetary Science Letters, 121, 435-449.

CAYTROUGH (1979). Geological and geophysical investigation of the Mid-Cayman Rise spreading center, initial results and observations. In M. Talwani, C. G. Harrison, \& D. E. Hayes (Eds.), Deep drilling results in the Atlantic Ocean, Oceanic Crust (Vol. 2) (pp. 66-93). Maurice Ewing series, AGU.

Chian, D., Keen, C., Reid, I., \& Louden, K. E. (1995). Evolution of nonvolcanic rifted margins: New results from the conjugate margins of the Labrador Sea. Geology, 23, 589-592.

Christensen, N. I. (1966). Elasticity of ultrabasic rocks. Journal of Geophysical Research, 71, 5921-5931.

Coakley, B. J., \& Cochran, J. R. (1998). Gravity evidence of very thin crust at the Gakkel Ridge (Arctic Ocean). Earth and Planetary Science Letters, 162, 81-95.

DeMets, C., Gordon, R. G., Argus, D. F., \& Stein, S. (1990). Current plate motions. Geophysical Journal of Royal Astronomical Society, 101, 425-478.

Dillon, W. P., Edgar, N. T., Parson, L. M., Scanlon, K. M., Driscoll, G. R., \& Jacobs, C (1993). Magnetic anomaly map of the central Cayman Trough, northwestern Caribbean Sea. US Geological Survey. Miscellaneous field studies Map, MF-2083 B.

Dillon, W. P., \& Vedder, J. G. (1973). Structure and development of the continental margin of British Honduras. Geological Society of American Bulletin, 84, 2713-2732.

Dillon, W. P., Vedder, J. G., \& Graf, R. J. (1972). Structural profile of the northwest Caribbean. Earth and Planetary Science Letters, 17, $175-180$

Dixon, T. H., Farina, F., DeMets, C., Jansma, P. E., Mann, P., \& Calais, E. (1998). Relative motion between the Caribbean and North American plates and related boundary zone deformation from a decade of GPS observations. Journal of Geophysical Research, 103, 15157-15182.

Ewing, J., Antoine, J., \& Ewing, M. (1960). Geophysical measurements in the western Caribbean Sea and Gulf of Mexico. Journal of Geophysical Research, 65, 4087-4126.

Gordon, M. B., Mann, P., Caceres, D., \& Flores, R. (1997). Cenozoic tectonic history of the North America-Caribbean plate boundary zone in western Cuba. Journal of Geophysical Research, 102, $10055-10082$.

Gripp, A. E., \& Gordon, R. G. (1990). Current plate velocities relative to the hotspots incorporating the NUVEL-1 global plate motion model. Geophysical Research Letters, 17, 1109-1112.

Holcombe, T. L., Vogt, P. R., Matthews, J. E., \& Murchinson, R. R. (1973). Evidence for seafloor spreading in the Cayman Trough. Earth and Planetary Science Letters, 20, 357-371.

Hosford, A (2001). Crustal accretion and evolution at slow and ultra-slow spreading mid-ocean ridges. $\mathrm{PhD}$ thesis, MIT/WHOI Joint Program, $250 \mathrm{pp}$.

Jacobs, C. L., Edgar, N. T., Parson, L. M., Dillon, W. P., Scanlon, K. M., \& Holcombe, T. L. (1989) (Vol. 272). A revised bathymetry of the MidCayman Rise and central Cayman Trough using long range side-scan sonar, Deacon Laboratory, Institute of Oceanographic Sciences, 11p and chart.

Klein, E. M., \& Langmuir, C. H. (1987). Global correlations of ocean ridge basalt chemistry with axial depth and crustal thickness. Journal of Geophysical Research, 92, 8089-8115.

Ladd, J. W., Holcombe, T. L., Westbrook, G. K., \& Edgar, N. T. (1990). Caribbean marine geology; active margins of the plate boundary. In G. Dengo, \& J. E. Case (Eds.), The geology of North America, Vol. H: The Caribbean region (pp. 261-290). Decade of North American geology, Geological Society of America.

Leroy, S., Mauffret, A., Patriat, P., \& Mercier de Lepinay, B. (2000). An alternative interpretation of the Cayman trough evolution from a reidentification of magnetic anomalies. Geophysics Journal International, 141, 539-557.

Leroy, S., Mercier de Lepinay, B., Mauffret, A., \& Pubellier, M. (1996). Structural and tectonic evolution of the eastern Cayman Trough (Caribbean Sea) from seismic reflection data. American Association of Petroleum Geologists Bulletin, 80, 222-247.

Louden, K. E., Osler, J. C., Srivastava, S. P., \& Keen, C. E. (1996). Formation of oceanic crust at slow spreading rates: New constraints from an extinct spreading center in the Labrador Sea. Geology, 24, $771-774$.

Macdonald, K. C., \& Holcombe, T. L. (1978). Inversion of magnetic anomalies and seafloor spreading in the Cayman Trough. Earth and Planetary Science Letters, 40, 407-414.

Mann, P., Schubert, C., \& Burke, K. (1990). Review of Caribbean neotectonics. In G. Dengo, \& J. E. Case (Eds.), The geology of North America, Vol. H: The Caribbean region (pp. 307-338). Decade of North American geology, Geological Society of America.

Molnar, P., \& Sykes, L. (1969). Tectonics of the Caribbean and Middle America regions from focal mechanisms and seismicity. Geological Society of American Bulletin, 80, 1639-1684.

Neumann, G. A., \& Forsyth, D. W. (1993). Comparison of marine gravity from shipboard and high-density satellite altimetry along the MidAtlantic Ridge, $30.5^{\circ}-35.5^{\circ} \mathrm{S}$. Geophysical Research Letters, 20 , $1639-1642$.

Perfit, M. R. (1977). Petrology and geochemistry of mafic rocks from the Cayman Trench; evidence for spreading, Geology, 5, $105-110$.

Perfit, M. R., \& Heezen, B. C. (1978). The geology and evolution of the Cayman Trench. Geological Society of American Bulletin, 89, $1155-1174$.

Pindell, J. L., \& Barrett, S. F. (1990). In G. Dengo, \& J. E. Case (Eds.), The geology of North America, Vol. H: The Caribbean region (pp. 405-432). Decade of North American geology, Geological Society of America.

Prince, R. A., \& Forsyth, D. W. (1988). Horizontal extent of anomalously thin crust near the Vema fracture zone from the three-dimensional analysis of gravity data. Journal of Geophysical Research, 93, 18051-18063.

Rosencrantz, E., \& Mann, P. (1991). SeaMarc II mapping of transform faults in the Cayman Trough, Caribbean Sea, Geology, $v 19$, 690-693.

Rosencrantz, E., Ross, M. I., \& Sclater, J. G. (1988). Age and spreading history in the Cayman Trough as determined from depth, heat flow, and magnetic anomalies. Journal of Geophysical Research, 93, 2141-2157.

Rosencrantz, E., \& Sclater, J. G. (1986). Depth and age in the Cayman Trough. Earth and Planetary Science Letters, 79, 133-144.

Sandwell, D. T., \& Smith, W. H. F. (1997). Marine gravity anomaly from Geosat and ERS 1 satellite altimetry. Journal of Geophysical Research, 102, 10039-10054.

Small, C., \& Sandwell, D. T. (1992). A comparison of satellite and shipboard gravity measurements in the Gulf of Mexico. Geophysics, 57, 885-893.

Smith, W. H. F., \& Wessel, P. (1991). Gridding with continuous curvature splines in tension. Geophysics, 55, 293-305. 
Stroup, J. B., \& Fox, P. J. (1981). Geologic investigations in the Cayman Trough: Evidence for thin crust along the Mid-Cayman Rise. Journal of Geology, 89, 395-420.

Tucholke, B. E., \& Lin, J. (1994). A geological model for structure of ridge segments in slow spreading ocean crust. Journal of Geophysical Research, 99, 11937-11958.

Wessel, P. (1989). XOVER, a cross-over error detector for track data. Computers and Geosciences, 15, 333-346.
Whitmarsh, R. B., \& Miles, P. R. (1995). Models of the development of the West Ibeeria rifted continental margin at $40^{\circ} 30^{\prime} \mathrm{N}$ deduced from surface and deep-tow magnetic anomalies. Journal of Geophysical Research, 100, 3789-3806.

Whitmarsh, R. B., White, R. S., Horsefield, S. J., Sibuet, J. C., Recq, M., \& Louvel, V. (1996). The ocean-continent boundary off the western continental margin of Iberia: Crustal structure west of Galicia Bank. Journal of Geophysical Research, 101, 28291-28314. 